NBER WORKING PAPER SERIES

CORPS INTERMÉDIAIRES, CIVIL SOCIETY, AND THE ART OF ASSOCIATION

Jacob T. Levy

Working Paper 21254

http://www.nber.org/papers/w21254

\author{
NATIONAL BUREAU OF ECONOMIC RESEARCH \\ 1050 Massachusetts Avenue \\ Cambridge, MA 02138 \\ June 2015
}

This research was supported in part by a grant from the Social Sciences and Humanities Research Council of Canada. The views expressed herein are those of the author and do not necessarily reflect the views of the National Bureau of Economic Research.

NBER working papers are circulated for discussion and comment purposes. They have not been peerreviewed or been subject to the review by the NBER Board of Directors that accompanies official NBER publications.

(C) 2015 by Jacob T. Levy. All rights reserved. Short sections of text, not to exceed two paragraphs, may be quoted without explicit permission provided that full credit, including $\odot$ notice, is given to the source. 
Corps Intermédiaires, Civil Society, and the Art of Association

Jacob T. Levy

NBER Working Paper No. 21254

June 2015

JEL No. B12,L30,N10

\begin{abstract}
$\underline{\text { ABSTRACT }}$
This paper races the shifts in treatments of intermediate groups among some liberal and democratic political theorists in the 18th and 19th centuries. The decades of the late 18th and early 19th centuries are traditionally understood to encompass the emergence of fully liberal political and social theory, and an early version of liberal political practice, in France, the UK, and the US; they have lately been identified by North, Wallis, and Weingast as the decades when those three societies substantially made the transition to "open access" political, economic, and legal orders. This transition consists in part in the democratization of organizational tools that had previously been open only to members of the elite, such as the shift from specially chartered monopolistic corporations to general incorporation laws, and that from parliamentary oligopolistic party competition to modern parties competing in wide-suffrage elections. Although the early liberal theorists did not fully perceive the changes happening around them, their analyses and reactions can help us see things about the shift to open-access orders that might not be fully visible in retrospect. To varying degrees they looked forward to the possibility of a pluralism without privilege, but they also had doubts about its possibility. They offered some reasons to prefer pluralism with privilege to the absence of both. They worried that centralization, democratic or otherwise, might be the preeminent fact of modern state consolidation, and that purely voluntary, equal, associational pluralism might not be powerful enough to check it. The kinds of pluralism grounded in ancient regime privilege and status, in entrenched jurisdictional pluralism within the constitutional order, or in pre-political cultural and customary ties might be needed to motivate the oppositional political action that could protect pluralism and freedom.
\end{abstract}

Jacob T. Levy

McGill University

jtlevy@gmail.com 


\title{
Corps Intermédiaires, Civil Society, and the Art of Association
}

\author{
Jacob T. Levy ${ }^{1}$
}

NBER Working Paper, in preparation for inclusion in Naomi R. Lamoreaux and John J. Wallis, eds., Organizations, Civil Society, and the Roots of Development

I.

This chapter traces the shifts in treatments of intermediate groups among some liberal and democratic political theorists in the $18^{\text {th }}$ and $19^{\text {th }}$ centuries. The decades of the late $18^{\text {th }}$ and early $19^{\text {th }}$ centuries are traditionally understood to encompass the emergence of fully liberal political and social theory, and an early version of liberal political practice, in France, the UK, and the US; they have lately been identified by North, Wallis, and Weingast as the decades when those three societies substantially made the transition to "open access" political, economic, and legal orders. $^{2}$ This transition consists in part in the democratization of organizational tools that had previously been open only to members of the elite, such as the shift from specially chartered monopolistic corporations to general incorporation laws, and that from parliamentary oligopolistic party competition to modern parties competing in wide-suffrage elections. Although the early liberal theorists did not fully perceive the changes happening around them, their analyses and reactions can help us see things about the shift to open-access orders that might not be fully visible in retrospect. To varying degrees they looked forward to the possibility

${ }^{1}$ Tomlinson Professor of Political Theory, McGill University. Thanks to Emma Rothschild, John Wallis, and Naomi Lamoreaux for comments. Portions of this essay draw from my Rationalism, Pluralism, and Freedom, Oxford University Press, 2014.

${ }^{2}$ Douglass North, John Wallis, and Barry Weingast, Violence and Social Orders, Cambridge: Cambridge University Press, 2009. 
of a pluralism without privilege, but they also had doubts about its possibility. They offered some reasons to prefer pluralism with privilege to the absence of both. They worried that centralization, democratic or otherwise, might be the preeminent fact of modern state consolidation, and that purely voluntary, equal, associational pluralism might not be powerful enough to check it. The kinds of pluralism grounded in ancient regime privilege and status, in entrenched jurisdictional pluralism within the constitutional order, or in pre-political cultural and customary ties might be needed to motivate the oppositional political action that could protect pluralism and freedom.

I begin with three simplified ways of thinking about the relationships among intermediate bodies and between them and the larger society, models that are deliberately stylized and abstract. These do not necessarily describe different types of groups or different legal regimes governing group life; the same groups might interact with each other or with the larger society in any or all of them.

First, and perhaps most typical of open-access orders, groups and associations might be thought of as competitive with one another, analogously to the competitive character of incorporated firms in an open market under laws of general incorporation. The associations that exist, and their relative success, represent the choices made by members who have the right to form, join, and exit groups relatively easily. Universities and private schools compete for students and teachers; religious denominations under conditions of religious freedom compete for adherents; municipalities compete for residents and capital through Tiebout sorting and as the 
kind of agents in a polycentric order analyzed by Elinor and Vincent Ostrom ${ }^{3}$; political parties compete for votes and members. Different activist groups devoted to the same issue, or different recreational or fraternal clubs of the same type, might compete with each other as well. Competitive groups are generally conceived of as similar enough and as having members who are similar enough that they are meaningfully rivalrous; a church is not competitive with a municipality in the same way. They are also understood as horizontally organized, each facing its rivals on more or less the same level. This competitive understanding of intermediate groups is congenial to the analysis of the open access order found in North, Wallis, and Weingast; it also figures prominently in Ernest Gellner's account of civil society, an order populated by "modular man" who can leave one group and join another without essential change in his identity or status. ${ }^{4}$ The competition of course relies in part on the kind of "exit" described by Albert Hirschman, but that feature is easily overstated; exit might happen only at the margins and yet

${ }^{3}$ See, for example, Governing the Commons: The Evolution of Institutions for Collective Action. Cambridge; New York: Cambridge University Press, 1990; Vincent Ostrom, Charles M. Tiebout and Robert Warren, "The Organization of Government in Metropolitan Areas: A Theoretical Inquiry.” American Political Science Review 55(5): 831-842, 1961; Charles M. Tiebout, “A Pure Theory of Local Expenditures," Journal of Political Economy, 64(5):416-424, 1956; and compare Barry Weingast, "The Economic Role of Political Institutions: Market-Preserving Federalism and Economic Development," 11 Journal of Law, Economics, and Organization 1$31,1995$.

${ }^{4}$ Ernest Gellner, The Conditions of Liberty, Penguin, 1994. 
exert important disciplining effects on group that are otherwise characterized by a great deal of loyalty and voice. ${ }^{5}$

Second, group life might be thought of as an integrative phenomenon. In the service of common and overarching ends, there is value in local participation and the sense of personal agency that comes of being part of a sub-group, and so smaller groups can be a way of drawing their members into overarching ones. Here the analytical emphasis is vertical, not horizontal, and the coexistence of groups of the same kind at the same level is comparatively unimportant. They might not be ruled out; each parish might have its own school and its own poor relief as the instantiation of communal projects of education and charity. Each town in an administratively decentralized unitary state might have its own local officials who implement the centrallydecided policies. A variety of groups at the same horizontal level are often, in integrative models drawn together into the larger whole. But their plurality is not in itself the point; they are only the local, visible, accessible aspect of a larger whole.

Integrative group life, in which groups interact as parts and wholes, cooperatively rather than competitively, is perhaps most widely known in social theory through the doctrine of subsidiarity in Catholic social thought. Subsidiarity emphasizes the importance of local decisions and actions, of local group life, within the context of an organically integrated whole community, whether that be the Church as such or social life more generally. In a different intellectual tradition, the corporations that mediate citizenship in Hegel's Philosophy of Right are organized by industry and profession, with no mention of or apparent value in having (say) competing corporations of lawyers.

\footnotetext{
${ }^{5}$ Albert Hirschman, Exit, Voice, and Loyalty, Harvard University Press, 1970.
} 
The "deep diversity" advocated by Charles Taylor — at once perhaps the leading living Catholic political philosopher and the leading living Hegelian political philosopher-treats smaller units as ways of belonging to the larger. These need not all represent the same way of belonging. Quebec, in Taylor's vision, represents a different mode of belonging to Canada, a substantively different type of membership in the federation, from the other provinces. But that does not mean that the other provinces which lack that distinctiveness should be abolished, only that they do not mediate membership in Canada in the same thick way that Quebec does. In any case, the question for everyone is "how do we belong to Canada?", that is, how do our intermediate groups (literally) mediate our membership in the larger whole?

If there is a political economy analogue of integrative models it is corporatism of various kinds, including the postwar corporatist model in some European countries whereby encompassing organizations representing labor and capital negotiated nationwide agreements with the help of a government concerned with the whole economic system. But there are uses of this analytical style that are neither so metaphysically fraught nor so concerned with organizations actually being organized hierarchically. The so-called neo-Tocquevillean studies of associational life associated with Robert Putnam also emphasize belonging to associations as a way of belonging to a larger social whole, united by bonds of trust and building social capital for the benefit of the whole community.

Third, we might think of group life as oppositional. If the competitive model emphasizes horizontal rivalry, and the integrative model emphasizes harmonious non-rivalry, the

\footnotetext{
${ }^{6}$ Most famously in Multiculturalism and The Politics of Recognition. Princeton: Princeton University Press, 1993. See also "Shared and Divergent Values," in Reconciling the Solitudes, Montreal and Kingston: McGill-Queen’s University Press, 1993.
} 
oppositional model emphasizes vertical rivalry: our local or particular or intermediate group offers the possibility of dissent, difference, or resistance. The church provides its members with social norms that meaningfully differ from those of the wider society, and the organizational resources with which to defend their religious liberty against church intrusion. Any type of adversarial federalist theory-the intercession theories of the Kentucky and Virginia Resolutions, the rivalry for loyalties between states and center envisioned in Federalist \#s 45-46, the Hapsburg-inspired multinational federalism defended in Lord Acton's On Nationality-uses these lenses, emphasizing not that (e.g.) Quebec is how I belong to Canada, but rather that it is how I sometimes do not, that it is the place where I can stand when I wish to say no to Canada. ${ }^{7}$ Dissenting churches under religious establishment obviously lend themselves to this kind of analysis, but orthodox or established churches can too, when they have enough institutional weight to counterbalance decisions made by political elites and state actors. An oppositional stance is relative to another group or set of groups: the medieval walled city might be seen as oppositional relative to the local lord but as having an integrative relationship with the politicaleconomic order of the kingdom as a whole, while the walled university or the church giving sanctuary might be oppositional relative to the city.

With these three models in mind, it would be easy to think of the emergence of liberalism, of civil society in the contemporary sense, and of open-access orders as being a

\footnotetext{
${ }^{7}$ In my "Federalism, Liberalism, and the Separation of Loyalties," 101(3) American Political Science Review 459-77, 2007, I discuss some of these cases in the context of offering an oppositional understanding of federalism, distinct from both competitive federalism and subsidiarity, though I did not there use the competitive/ integrative/ oppositional typology or draw the connections to questions of associational life and civil society.
} 
matter of the replacement of integrative and oppositional styles of group relations with a competitive model. I hope to show that matters were, and remain, more complicated than that. I will draw on theorists who lived through the transition to early open access societies to suggest that the competitive mode of group relations might not be self-sufficient. The open-access order may remain dependent on institutional inheritances and forms from what North, Wallis, and Weingast term the "mature natural state," "characterized by durable institutional structures for the state and the ability to support elite organizations outside the immediate framework of the state, $" 8$ in order to undergird, in particular, pluralism of the oppositional type.

II.

Montesquieu's 1748 The Spirit of the Laws famously identified corps intermédiaires as the crucial constitutional pillars of a moderate monarchy. ${ }^{9}$ Montesquieu treated the defense of cities', provinces' guilds', and the Church's self-government as a part of the defense of limitations on centralized state power, the kinds of limits that were sorely needed in the era of

${ }^{8}$ Violence and Social Orders, 47 . They add "at the limit, a mature natural state is able o create and sustain perpetually lived organizations, but that is not a common feature of mature natural states." Common or not, the perpetually-lived organizations with independent legal personality, the corps with corporate form, were very much a feature of the mature natural states that we find in early modern, pre-Revolutionary Europe. Since the theorists I discuss here take the possibility of the corps for granted, I will not discuss the alternative of mature natural states that lack them. See also Violence and Social Orders pp. 158-69.

${ }^{9}$ The Spirit of the Laws. edited by Anne M Cohler, Basia Carolyn Miller, and Harold Samuel Stone. Cambridge; New York: Cambridge University Press, 1989[1748], henceforth SL. 
would-be absolutist kings. The argument depended on both the quasi-public or public character of the corps (their privileges made up part of the constitutional order) and their base in extralegal social facts not susceptible to direct royal intervention (such as the nobility's attachment to their honor). Montesquieu's was an oppositional pluralism that drew its strength from privilege; drawing on their respective social bases of support and appealing to law, the corps could limit monarchies and prevent them from degenerating into despotism.

Montesquieu distinguished moderate monarchies and immoderate despotisms on the basis of the former's respect for corps intermédiaires. "Intermediate, subordinate, and dependent powers constitute the nature of monarchical government, that is, of the government in which one alone governs by fundamental laws." The "lords, clergy, nobility, and towns" maintain a monarchy in its proper conceptual form. The most "natural" intermediate power is the nobility as a class, so much so that "nobility is the essence of a monarchy, whose fundamental maxim is: no monarch, no nobility; no nobility, no monarch; rather, one has a despot." Even the Church, which he sharply criticizes for intolerance and persecution, has a crucial role to play, and he suggests that ecclesiastical autonomy should be respected and legally firmly established. It provides the final check against despotism when a monarchy has otherwise abolished all of its old laws. Montesquieu's defense of the corps intermediaires is a genuine theory of intermediacy. The aristocracy in a monarchy defends the laws; aristocratic government without a monarch to overawe the nobles tends toward lawlessness and corruption. Their privileges are "odious in themselves," but instrumentally useful in aligning their honor with the defense of the constitution. ${ }^{11}$

\footnotetext{
${ }^{10}$ SL, II.4, p. 17.

${ }^{11} S L$ II.11.6, p. 161.
} 
The argument was in part conceptual, in part causal. Montesquieu both claimed that a monarchy could be identified by the presence of intermediate bodies, and that the intermediate bodies help to keep monarchies moderate. The former idea is interesting insofar as it marks an unusual addition to an intellectual tradition as old as Aristotle's Politics. Montesquieu did not disagree with the traditional view that monarchies are law-governed and despotisms lawless and arbitrary. Lawfulness and lawlessness distinguish his moderate regimes as a group from the immoderate category of despotism. But he did not simply hold that monarchies were lawful rule-by-one. He instead suggested that lawful rule-by-one would necessarily entail the persistence of intermediate groups.

Moreover, and more fundamentally, he held that monarchies could only remain moderate and lawful regimes over time because of the continued existence of the corps. As their liberties and privileges diminished, the monarchy would slip farther and farther toward despotism. This was because only the corps could have both the motivation and the power to successfully check the urge of monarchs to absolutism. Without them, there is no one to say no to the king, and certainly not to do so in the name of law. Of special importance are those intermediate bodies he calls the "depositories of the laws" as they will have a special connection with the retention and enforcement of legality and liberties: in France, the aristocratic courts known as parlements, which even in their weakened eighteenth-century state "do much good."12

Montesquieu admired the British constitution, the subject of extended discussions in II.11 and III.19. But his enthusiasm for England's system was limited precisely by the decline of England's corps since the Civil War. "If you abolish the prerogatives of the lords, clergy,

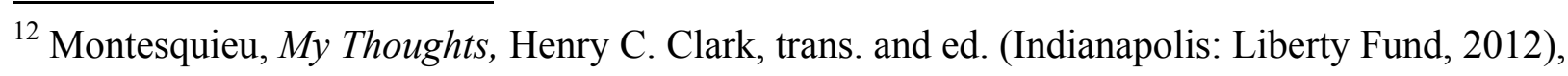
p. 192.
} 
nobility, and towns in a monarchy, you will soon have a popular state or else a despotic state[...] In order to favor liberty, the English have removed all the intermediate powers that formed their monarchy. They are quite right to preserve that liberty," he drily concludes; "if they were to lose it, they would be one of the most enslaved peoples on earth" because of their abolition of intermediate powers. ${ }^{13}$ This perilous state of affairs dates from the days of Cromwell; "the English nobility was buried with Charles I in the debris of the throne."14

The conviction that the corps, including those staffed by a hereditary nobility, are crucial to the maintenance of a lawful and balanced monarchy helps to explain Montesquieu's apparently-odd identification of honor as the animating principle of a monarchy. Aristocratic honor, after all, does not derive directly or solely from the monarch, but rather from a sense of the dignity and respect is due, as a matter of family standing and personal merit. For aristocrats who are drawn to court, i.e. Versailles, the monarch has an outsized influence on their status and standing. But those driven by honor could not be the kinds of subservient flatterers demanded by despots. They could not help but stand up for the dignity of their own offices and authority. Indeed they could not even be counted on to obey direct royal commands. Dueling, the "point of honor," had long been illegal but was still fairly common, and aristocratic officers had been known to disobey orders that we would think of as war crimes but they construed as dishonorable. However poorly-justified a person's view of his own honor might be, it remained his, not only outside the direct control of the monarch but sometimes a psychological source of

\footnotetext{
${ }^{13}$ SL, II.4, pp. $18-19$

${ }^{14}$ SL, VIII.9, p. 118.
} 
the willingness to resist him. ${ }^{15}$ If the corps were needed to affirm and enforce legal limits on royal power and prevent despotism, honor was needed to animate the corps, and to keep their members dedicated to their defense. This is why, notwithstanding the "ignorance natural to the nobility, its laxity, and its scorn for civil government," ${ }^{, 16}$ it is the sine qua non of lawful and moderate monarchy.

Montesquieu critiqued the turn to absolutism and centralization under Louis XIV, albeit always with a slight, politic opacity. The recurring comparisons and contrasts between monarchies and despotisms often come just to the edge of saying that Bourbon France had crossed, or risked crossing, the line between them. The corps had been steadily undermined in "a great European state" over the preceding centuries. "In certain European monarchies" the autonomous provinces that govern themselves well and thus thrive are constantly threatened with the loss of "the very government that produces the good," to better allow them to "pay even more." ${ }^{\prime 17}$ This strategy of killing the golden goose is another sign of despotism; "when the

${ }^{15}$ For discussions of honor as a source of strength for political resistance, though in a more democratic spirit, see Sharon Krause, Liberalism With Honor (Cambridge: Harvard University Press, 2002), and Anthony Appiah, The Honor Code (New York: W. W. Norton, 2010).

${ }^{16}$ SL, II.4, p. 19

${ }^{17}$ SL, II.13.12, p. 221. For an account of Montesquieu's defense of provincial autonomy that amounts to a kind of federalist constitutionalism for monarchies, see Lee Ward, "Montesquieu on Federalism and Anglo-Gothic Constitutionalism," 37(4) Publius: The Journal of Federalism 551-577, 2009. 
savages of Louisiana want fruit, they cut down the tree and gather the fruit. There you have despotic government." 18

The deliberate effort to draw the aristocracy in to the court at Versailles and cut them off from the provinces likewise concerned Montesquieu. In an essay on "the grandeur of the capital" in his unpublished Pensées, he added that criterion to his distinctions among regimes. A great capital would destroy a republic, but was natural to despotism. In a monarchy things were complicated and required balance. The growth of London was not especially worrisome, as it arose from the attractions of commerce. But a monarchy could also grow in the capital due to onerous taxes in the provinces, or to administrative procedures that demanded a presence in the capital to settle legal questions, or to the sheer attractions in terms of honor of the monarchical court. One way to maintain balance, unsurprisingly, was to "let cases before the provincial courts be settled in those courts and not appealed endlessly" to the tribunals at the center. ${ }^{19}$ But Louis XIV had sought to aggravate the imbalance rather than counteract it.

Montesquieu added to his political and constitutional critique of despotic uniformity an understanding of a social world autonomous of, and not created by, political rule. Geography and climate, historical and cultural change, economic forces, and religion all constrained in various ways what rulers could do-and in different ways in different places. In these parts of the book we find a recurring motif of advice to legislators and rulers to notice the particularities of their societies and govern accordingly, rather than in accordance with abstract plans. Like his followers for the rest of the eighteenth century — classical economists elaborating of an economic world that transcended political boundaries and operated according to its own discoverable rules,

\footnotetext{
${ }^{18}$ SL, I.5.13 p. 59

${ }^{19}$ See Daniel Roche, France in the Enlightenment, pp. 209-210.
} 
and that partly conditioned and limited politics, social theorists studying manners and moresMontesquieu sought to describe societies rather than simply polities. ${ }^{20}$

Besides understanding the existence of such social worlds, Montesquieu (and those who followed him in this regard) tried to understand their plasticity or limits, and the rules according to which they changed and developed. Social worlds were not static; manners could become more polished over time, the wealth of nations could grow or decline, agricultural societies could become commercial societies, and so on. But none of these things happened by simple political decree. Governing should usually be done along the grain of such social tendencies and local particularities, occasionally in a way that might counterbalance some undesirable tendency, but never in sheer ignorance of or violence against them. The moeurs, manners, and customs of a society create a cultural reality that one may attempt to guide in one direction or another but that cannot be simply ruled. Montesquieu's discussion of Peter the Great's attempts to Europeanize Russia stands out here. He sought to change the "manners" of his people by laws and coercion, and disregarded their legitimate attachment to custom; the results were violence and tyranny. As with attempts to abolish the corps, attempts to legislate past the limits of the plasticity of the social world both constituted despotism and encouraged it. They sought to criminalize cultural and religious practices; and when they failed, their authors would resort to more and more severe measures in response.

Near the end of $S L$ we find a remarkable chapter on the idea of uniformity of laws, against which Montesquieu warns the would-be legislator.

${ }^{20}$ This is the sense in which Durkheim saw Montesqueiu as a founder of sociology, set apart from political philosophy. See also Taylor, "Invoking Civil Society." 
"There are certain ideas of uniformity, which sometimes strike great geniuses (for they even affected Charlemagne), but infallibly make an impression on little souls. They discover therein a kind of perfection, which they recognize because it is impossible for them not to see it; the same authorized weights, the same measures in trade, the same laws in the state, the same religion in all its parts. But is this always right and without exception? Is the evil of changing constantly less than that of suffering? And does not a greatness of genius consist rather in distinguishing between those cases in which uniformity is requisite, and those in which there is a necessity for differences? In China the Chinese are governed by the Chinese ceremonial and the Tartars by theirs; and yet there is no nation in the world that aims so much at tranquility. If the people observe the laws, what signifies it whether these laws are the same?"21

Near the beginning of the book Montesquieu had said that when a ruler "makes himself more absolute, his first thought is to simplify the laws." 22 Then, it had appeared as something like a deliberate strategy, as the simplified state would be simpler to rule. But at the end of the book it appears rather as an unjustified taste or a psychological affliction of those who hold power or make laws. Shortly before the remarks on uniformity, he wrote that "it seems to me that I have written this work only to prove $[\ldots]$ that the spirit of moderation should be that of the legislator; the political good, like the moral good, is always found between two limits." ${ }^{23}$ But the spirit of moderation was not normally or naturally that of the legislator.

\footnotetext{
${ }^{21}$ Montesquieu, Spirit of the Laws, Anne M. Cohler, Basia Carolyn Miller, and Harold Samuel Stone, eds. (Cambridge: Cambridge University Press, 1989[1748]), henceforth SL, VI.29.18, p. 617

${ }^{22} S L$, I.6.2, p. 75

${ }^{23} S L$, VI.29.1, p. 602.
} 
These statements of purpose accompany, indeed interrupt, a long study of the problems of Roman, Germanic, and feudal law in the French legal order. This large part of $S L$ is frequently obscure to the modern Anglophone reader; indeed it was obscure to some contemporaneous French readers. But they are less obscure when read in light of the preceding two centuries' debate about the ancient constitution.

There were three primary theses about the French traditional constitution. The royal thesis saw a more or less seamless transition from Roman imperial rule to the French kingdom. The democratic-leaning Protestant and Germanic thesis was one of primordial freedom and equality. And the view influentially put forward by the Comte de Boullainvilliers a generation before $S L$ was one of Frankish conquest yielding absolute rule over the conquered, and Germanic parity governing only as between the nobles and their king.

Montesquieu pairs the Germanist account of popular government with Boulainvilliers' aristocratic thesis as comparable mistakes, one privileging the Third Estate and one the nobility, both unduly. ${ }^{24}$ He takes a sharply unconventional approach to the disputes as to the foundations of French law. In the first place, it is directly concerned with what Montesquieu terms "civil" rather than "political" law_in our terms, mainly private and criminal law rather than constitutional public law. It offers a history of laws under the French monarchy, not a history of the founding of that monarchy or of its aristocracy. The Salic Law was not a constitutional enactment; it was simply the then-extant law of inheritance of fiefs applied to the case of royal inheritance. Civil law generated political law.

\footnotetext{
${ }^{24}$ Sylvana Tomaselli, "The Spirit of Nations," section 7: "The spirit of the laws: the Gothic constitution"
} 
Secondly, it declines to adopt any of the traditional sides in the constitutional dispute, neither the Romanist Gallic account of continuity with the fallen empire nor the Germanist Frankish story of primeval liberty. Rather, he stressed, the civil laws in France had always been diverse and pluralistic. Insofar as the law was of barbarian Germanic origin, it was not simply Frankish law imposed — for, as he stresses here and elsewhere, the idea that conquerors should be legislators and replace the laws and customs of the conquered is a modern one. Instead, it was the laws of the Ripuarian and the Salic Franks and the Saxons, and elsewhere the relatively Romanized barbarian codes of the Burgundians and Visigoths and Lombards and so on. Roman law was retained for Romans; gradually only the clergy retained it, as others opted into one or another of the surrounding legal codes. The independence of canon law thus appears as a foundational fact about French law. So, too, does legal pluralism more generally.

As the Roman and barbarian legal codes fell into disuse, they were succeeded by a variety of territorial, regional, and eventually provincial customs. These were inflected, to be sure, with local inheritances from the old codes (Frankish, Gothic, and so on) but became detached from the old personal identities. The recovered corpus of Justinian was received in relatively Romanized provinces as written law, as it formalized existing practice; elsewhere, it was admitted only as ratio scripta. This re-writtenness of the Roman law was paralleled by a newfound writtenness of customary law in other provinces. The rise of feudalism provided another source of pluralism, as each lord held court in his own manor. The early Middle Ages appear as a time of "prodigious diversity" in law—not indeed the same diversity which had characterized early medieval France under the barbarian codes, but such that (as he approvingly quotes Beaumanoir as saying) no two lordships had entirely the same civil law in all of France. 
And finally, Montesquieu attempts to show that this situation was not interrupted in the thirteenth century by the so-called Establishments of St. Louis (King Louis IX), a document that was sometimes appealed to as being the foundation of a unified civil code, but that he said.

"was never made to serve as law for the whole kingdom... Now, at a time when each town, borough, or village had its own custom, to give a general body of civil laws [would have been] to reverse in a moment all the particular laws under which men had lived everywhere in the kingdom. To make a general custom of all the particular customs would be rash, even in these times..." ${ }^{25}$

Montesquieu's distinctive legal history in $S L$ determinedly does not identify any particular founding moment that normatively defines the kingdom thenceforth. He denies that France was simply Roman or simply Frankish, tracing instead the ebb and flow of different types of law and rules governing choice of law. The Salic Law had some pride of place, to be sure; it was the territorial law of the royal demesne. But Montesquieu refuses to indulge the fiction that this made it the law of the kingdom. He maintains that the French legal order had always been a pluralistic one in which different rules coexisted; and that pluralism itself evolved over time, as rules of personal jurisdiction gave way to provincial territorial jurisdiction, as the Roman law was recovered, as feudalism developed, as persons opted into one court system or another for their own various reasons. The aspiration to legal uniformity was thus at odds with the kingdom's whole history. The variety of provincial laws protected by the provincial parlements, the coexistence of civil and canon law, of urban and seigniorial law-these were the complex fabric of French law, and the contemporary legislative reformer must not pretend otherwise. In short, the moderate constitutional monarchy characterized corps that represented and protected

${ }^{25} S L$, VI.28.37, p. 589. 
social variety was grounded in the whole constitutional history of the kingdom. Unity and uniformity—whether democratic, aristocratic, or monarchical—were modern fantasies projected back through time, not founding truths.

While Montesquieu's multistranded defense of pluralism and the privileges of the corps was highly influential through the eighteenth century, two rivals to it were as well. One, the civic republican suspicion of factions, was associated with Rousseau, Mably, and Sièyes as well as with important strands in the American and French Revolutions. The elevation of extralegal social pluralism into a public constitutional fact became identified with both intolerable privilege and illegitimate disunity. The other, a rationalistic individualism, looked forward to the use of modernized state power to check or abolish the corps, not backward toward imagined pasts of uncorrupted unity. It is in principle distinguishable from the civic republican view, most prominently by its greater enthusiasm for commerce but also by its greater tolerance for associational pluralism provided that privilege was stripped away. The gradual shift from a civic republican suspicion of all factions in politics to a pluralist view that competitive factions (and, later, parties) might be attractive and necessary features of republican politics is well-known. And there is, I suspect, something to be said for the idea that this shift corresponds with (and contributes to) that from regulated intra-oligarchic contestation to the early open-access orders of the nineteenth century.

In the remainder of this essay, however, I follow an intellectual path from Montesquieu onward. Montesquieu and his successors wanted no part of the civic republican obsession with unity, but the pluralism they espoused was never only that of freely-created associations peacefully competing. Although Smith, Constant, and Tocqueville did value competitive 
associational life, they also followed Montesquieu in his attention to oppositional pluralism—and they offered reason to think that oppositional pluralism might require deeper social roots than open access and individual consent could provide.

III.

One of the first powerful analyses of associations as competitors appears in The Wealth of Nations' treatment of religious groups. ${ }^{26}$ It is of course not a coincidence that this analysis is offered by Adam Smith, in the course of a work that shows the beneficial consequences of competitive behavior in a range of domains and that is remembered as the key intellectual defense of free economic competition against oligarchic mercantile monopolies. His treatment in Book $\mathrm{V}$ of vibrant competition among churches for members, however, is very little like his examinations of marketplace behavior in Books I and II. His is not a model of parishoners casually shopping from one church to another at arm's length, but of believers being provided with community, structure, and meaning by sects that might counteract the anonymity and alienation of modern urban life.

The discussion is framed in part as a reply to David Hume's wry defense of an established church, an argument in favor of indolent salaried priests as against the tendency of a free religious marketplace to favor passionate religious enthusiasm and the sects that march a population toward religious civil war. Smith agrees with Hume that energetic and excessively rigorous churches will have a competitive advantage over their distant, lazy, bureaucratic counterparts. (Not to put too fine a point on it: they both saw the rise of Methodism at the

\footnotetext{
${ }^{26}$ Adam Smith, An Inquiry Into the Nature and Causes of the Wealth of Nations, Campbell, Skinner, and Todd, eds. (Indianapolis: Liberty Fund, 1981 [1776]), pp. 788-814.
} 
expense of traditional Anglicanism as recalling the earlier rise of Puritanism, and as examples of a general truth about religious competition.) He importantly disagrees about the political conclusion, arguing that in the absence of establishment, religious competition tends to multiply sects and to create diffuse contestation, not the concentrated type that can lead to civil war. Indeed, he blames the established bureaucratic churches, not their passionate opponents, for civil wars; it is the establishment that makes use of state power and elevates disagreement into organized violence. The critique of established churches resembles that of mercantilist monopolies: the privileged and powerful make illegitimate use of the state and entrench their own advantages. But his model of competitive behavior among the sects does not much resemble that his understanding of marketplace behavior. Indeed, the anonymous and arm's length character of market and city life partly create the need that passionate sects fulfill: a need for intense community based on strong emotional connection and mutual knowledge. Whereas commerce is generally a mild and moderating force in Smith's thought, moderation is precisely what doesn't result from religious competition. Competition does not turn religious life into something calm and rational, deliberately chosen and deliberately exited from. Rather, it changes the institutional setting for our expression of deep commitments, and can thereby serve valuable social functions (relief from anonymity, mitigation of social and moral decay in the city) rather than creating political dangers.

And this attention to the deep attachments we hold to our identities and memberships sometimes pushed Smith from a competitive to an oppositional understanding of pluralism, as in his indictment of the "man of system" in the final edition of The Theory of Moral Sentiments, published during, and generally presumed to be a comment on, the early stages of the French 
Revolution. $^{27}$ Its best-known lines have sometimes been read as if they were criticisms of centralized economic planning and treated as a kind of adjunct to The Wealth of Nations.

"The man of system, on the contrary, is apt to be very wise in his own conceit[...]He seems to imagine that he can arrange the different members of a great society with as much ease as the hand arranges the different pieces upon a chess-board. He does not consider that the pieces upon the chess-board have no other principle of motion besides that which the hand impresses upon them; but that, in the great chess-board of human society, every single piece has a principle of motion of its own, altogether different from that which the legislature might chuse to impress upon it."

In fact, the passage concerns constitutional reform, privilege, and politics, not economics at all. Smith's man of system bears a closer resemblance to Montesquieu's legislator of uniformity than to the modern would-be economic planner. In his desire to abolish privilege, the man of system proposes "to new-model the constitution, and to alter, in some of its most essential parts, that system of government under which the subjects of a great empire have enjoyed, perhaps, peace, security, and even glory, during the course of several centuries together." In seeking to implement the far-reaching reforms which appear in his mind as uniform, symmetrical, and beautiful, the man of system holds special fury for those elements of society that might have the constitutional power to obstruct them. "The great object of their reformation, therefore, is to remove those obstructions; to reduce the authority of the nobility; to take away the privileges of cities and provinces, and to render both the greatest individuals and the greatest orders of the state, as incapable of opposing their commands, as the weakest and most insignificant."

\footnotetext{
${ }^{27}$ Adam Smith, Theory of Moral Sentiments, Campbell and Skinner, eds. (Indianapolis: Liberty Classics, 1981[1790]), pp. 233-34.
} 
By contrast, "the man whose public spirit is prompted altogether by humanity and benevolence, will respect the established powers and privileges even of individuals, and still more those of the great orders and societies, into which the state is divided. Though he should consider some of them as in some measure abusive, he will content himself with moderating, what he often cannot annihilate without great violence."

In other words, while Smith sees that the differential privileges of the "orders and societies," the nobles, provinces, and cities, are often abusive ("odious in themselves," as Montesquieu put it), he also thinks that they serve as a valuable political and constitutional counterweight to centralized and rationalizing power. The wise reformer would seek to mitigate the abuses but not to abolish the special constitutional standing.

While the monopolistic privileges of an established church or of the mercantile companies normally tend to augment unitary central power, the constitutional privileges of a plurality of cities, provinces, or nobles can be quite different. Just as Montesquieu had seen, their various bases of independent social power mean that they are in a good position to oppose abuses on the part of the state itself, whether committed by "imperial and royal" centralizers or by the leaders of revolutionary factions.

Smith's discussion of the man of system includes the idea of competitive political parties of a sort - and party competition is the problem, not the solution. Moderate reform is less likely to appeal to the passionate partisan base than is wholesale abolition; even party leaders who know better may be radicalized by the competitive dynamic. And the bodies he names as moderating forces, the "orders and societies," could not be created by associational free competition: provinces are not clubs, and nobles are not a party. They are limited in number, privileged, and rest on or engender very particularistic commitments on the part of their members. 
In Smith we thus see a crucial range of treatments of pluralism, which includes not only the kind of competitive behavior among firms that we most associate with competition in openaccess orders, but also the passionate and particularistic competition among churches, and an oppositional status of privileged pluralistic orders. His appreciation for the value of something very like open access in the spheres of the market and religion coexisted with a not-entirelygrudging tolerance for the constitutional institutions of the mature natural state.

IV.

Benjamin Constant was the first major political theorist to call his thought "liberal" and to identify with liberalism as a party position. While we might think of Adam Smith as the most important exponent of a theory of open access markets, and James Madison as the crucial figure in developing an account of factional political competition through electoral politics, Constant is the first theorist of the emerging liberal order as a whole: freedom of religion, speech, and the press; due process of law and equality before the law; competitive and responsible representative democracy; free markets and free trade; and the elevation of individual private liberty to a privileged moral position. He famously opposed Rousseau's democratic holism and celebrated modern individuality. He could see the possibility of competitive pluralism without privilege, and he welcomed it. But he shared many of Montesquieu's and Smith's worries, as well.

Much of Constant's writing on associational pluralism did embrace competitive models, and defend group life as an aspect of individual freedom in the private sphere. He defended the proliferation of sects and denominations as a positive good, and as in any case inevitable wherever persons cared about religious questions enough to think about them, rather than mindlessly following empty rituals. Schism and proliferation tended-by competition-to 
improve the moral purity of all sects, as the Reformation improved a previously-corrupt Catholicism; and it also conduced to civil peace. Likewise, but more profoundly for understanding Constant: his religious sensibility was a romantic Protestant individualism. ${ }^{28} \mathrm{He}$ was instinctively unsympathetic to Catholicism and skeptical of all sacerdotal corporations: organized churches, a privileged priesthood, monastic orders. The religion to which he was so concerned to preserve free access was a religion of individual spirituality that develops the soul and the mind.

Yet he recognized that for many people their religious sentiments came to be tied up in external "forms," and that this was a reason for freedom of religious practice with respect to those forms - a freedom which had been violated under the Revolution. He supported the liberty to form and live in sacerdotal corporations such as monasteries. Provided that freedom of exit was protected, life within such corporations was an option legitimately open to free persons. "There are two ways of suppressing monasteries; you may open their doors; or you may drive out their occupants. If you adopt the first solution, you do something good without causing any harm; you break chains without violating refuges. If you adopt the second, you upset calculations based upon public faith; you insult old age, which you drag languishing and unarmed into an unknown world; you violate an incontestable right of all individuals in the

${ }^{28}$ For Constant on religion, see Helena Rosenblatt, Liberal Values: Benjamin Constant and the Politics of Religion; Bryan Garsten, "Constant on the Religious Spirit of Liberalism," in The Cambridge Companion to Constant, Rosenblatt, ed. (Cambridge: Cambridge University Press, 2009); Garsten, “Religion and the Case Against Ancient Liberty: Benjamin Constant's Other Lectures," 38 Political Theory 4-33, 2010. 
social state, the right to choose their own way of life, to hold their property in common, to gather in order to profess the same doctrine, to enjoy the same leisure, to savour the same rest.",29

These religious cases were of central importance to Constant, and they offer reason to think that he might have viewed group life competitively: break the chains, let the sects proliferate, open the doors, let believers choose. (Certainly he opposed the integrative style of thinking of the Catholic Church as providing believers with their way of belonging to France.) And often he emphasized that the pluralism of group life was tightly connected to the ordinary private liberty of living as one chooses, including in customary ways. In his most enduring work of political theory, "The Liberty of the Ancients Compared With That Of the Moderns," he held to the view that "the changes brought by the centuries require from the authorities greater respect for customs, for affections, for the independence of individuals. ${ }^{, 30}$ Habits and affections are a crucial part of a free person's happiness and, therefore, of his or her interests. In social life, particularly but not only in religion, the liberty of the moderns was closely tied to pluralism. Free people, not joined together by ancient republican devotion to the public, would not be socially homogenous.

But, like Smith, Constant drew on the oppositional style found in Montesquieu when it came to pluralism in the constitutional order.

\footnotetext{
29 "On innovation, reform, and the uniformity and stability of institutions;" chapter 1 of the material added to the fourth edition of Conquest and Usurpation; in Political Writings, p. 153. ${ }^{30}$ Constant, "Liberty of the Ancients Compared with that of the Moderns" (1819) in Political Writings, Fontana, ed. (Cambridge: Cambridge University Press, 1988), p. 324.
} 
Montesquieu's intellectual example was much Constant's mind as he composed his political writings in exile from Napoleon-one manuscript on the constitutional organization of republican government, the other on the principles of liberty that restrict what any government may legitimately do- which together provide the substance (and most of the words) of Constant's later political writings. (The two were originally envisioned as one Spirit of the Laws- style opus.) As he read Montesquieu while trying to write his own work, he wrote in his journal "What a keen and profound eye! All that he said, even in the smallest things, proves true every day." ${ }^{31}$

Constant's writings on legislated uniformity explicitly acknowledge his debt to Montesquieu before offering even sharper defenses of pluralism, in the wake of a generation of Jacobin and Bonapartist centralization. He argues both against the spirit of system that accompanies and initiates governors' desire to rationalize, and in active defense of the sentiments that attach people to their local traditions and rules. The desire to create order and rationality in society need not be destructive in itself; but it is too-easily joined with coercive force, as governors imagine that a uniform society will be more easily governed. "The spirit of system was first entranced by symmetry. The love of power soon discovered what immense advantages symmetry could procure for it." ${ }^{, 32}$ A kind of philosophical aesthetic motivated benevolent legislators in the first instance; but the desire for uniformity led to the destruction of the corps and non-state institutions, enhancing the relative power of the center and creating a dynamic that outraced that initial public-spirited impulse. With Montesquieu and against such uniformitycraving philosophes as Voltaire, he wrote sympathetically about the provincial variety of laws in

\footnotetext{
${ }^{31}$ Constant, Journaux Intimes January 28 1804, in Oeuvres, Roulin, ed. (Paris: Gallimard, 1957).

${ }^{32}$ Constant, "On Uniformity," in The Spirit of Conquest and Usurpation and Their Relation to
} European Civilization, (1814) in Political Writings, p. 74 
the old regime. ${ }^{33}$ The plurality of public jurisdictions and legal traditions attached people's natural sentiments of familiarity and home to the constitutional order. Rationalization from the center broke that tie.

Constant indicts the tendencies toward uniformity of centralized and metropolitan legislatures. The members of the latter tend to acquire an esprit de corps, identifying with each other and with the capital. So they "lose sight of the usages, needs, and way of life of their constituents. They lend themselves to general ideas of leveling, symmetry, uniformity, mass changes, and universal recasting, bringing upset, disorder, and confusion to distant regions. It is this disposition we must combat, because it is on particular memories, habits, and regional laws that the happiness and peace of a province rest. National assemblies are scornful and careless with these things." 34 The better course is to allow the cities and provinces to keep their natural hold on our affections. "The interests and memories that arise from local customs contain a germ of resistance that authority is reluctant to tolerate and that it is anxious to eradicate. It can deal more easily with individuals; it rolls its heavy body effortlessly over them as if they were sand." 35 That "germ of resistance" seems to me the crucial idea that runs throughout Constat's writings on pluralism and constitutionalism: the oppositional relationship between the various customary local jurisdictions and groupings on one hand, and the central state on the other.

\footnotetext{
${ }^{33}$ Constant, Conquest and Usurpation, in Political Writings, p. 154.

${ }^{34}$ Constant, Book XV ch. 4, “Application of This Principle to the Composition of Representative Assemblies," in Principles of Politics Applicable to All Governments, Dennis O’Keeffe, trans. (Indianapolis: Liberty Fund, 2003), p. 328.

${ }^{35}$ SCU, p. 74
} 
One of Constant's ur-texts from his years of writing in exile comes to us as the Fragments of an abandoned work on the possibility of a republican constitution in a large state, a possibility Montesquieu famously denied and one that Constant was at pains to establish. This work, dedicated to refuting one of the best-known of Montesquieu's arguments, is nonetheless steeped in Montesquieu's intellectual style and ideas. Constant understood that Montesquieu's skepticism was not aimed at the idea of freedom in a large state but at the idea of freedom in a republic. He thought that Montesquieu had looked at the virtuous, anti-commercial, unfree republics of antiquity and attributed those features to republics, when they were better attributed to the ancient era. ${ }^{36}$

This was Constant's position throughout his life: that freedom was possible in a large and extended republic, and that much that Montesquieu attributed to the spirit of a nation or of its laws is in fact attributable to the spirit of the age. Constant's political agenda never included the recreation of the ancient constitution of Montesquieu's time. But he sympathized with Montesquieu's defense of that constitution and tried to draw appropriate lessons from it; he did not view it as a defense of local tyranny and arbitrariness. On the central claim that intermediate bodies, a hereditary class, and corporations were essential for freedom, Montesquieu had been right to see them as the bulwarks of freedom against the king of his era. Their irrationality and inegalitarianism did not condemn them out of hand; uniformity under a tyrannical law was, for Constant as for Montesquieu, no virtue. The task for republican and post-Revolutionary thought was, in part, to find ways to recapture the pluralistic benefits without the abusive privilege.

\footnotetext{
${ }^{36}$ Constant, "Liberty of the Ancients Compared with that of the Moderns" in Political Writings.
} 
Constant criticized the idea of hereditary rights of rule and the existence of a hereditary principle in a constitution. But his understanding of Montesquieu's defense of such things was that under an "abusive" government, "heredity can be useful; where rights have disappeared, privileges offer asylum and defense. In spite of its inconveniences, heredity is better than the absence of any neutral power. The hereditary interest... creates a sort of neutrality. ${ }^{37}$ In order to dispose of heredity, it is necessary to have an excellent constitution. Montesquieu knew this; under the pressure of despotism there is a terrible leveling equality.",38

Constant agreed that a monarchy depended on an aristocracy in order to protect freedom; he differed from Montesquieu in insisting that the reverse was also true (a monarch might check the local tyranny of lords) and in maintaining that this provided an argument against monarchy altogether. He thought that the benefits of the ancient constitution's division of powers and classes could be simulated in an extended and federal republic; but he certainly agreed with Montesquieu that there had been such benefits. In the defenses of provincial and parlementaire rights and privileges, the ancien régime French conducted debates and engaged in struggles in which "everyone's heads were filled with the principles of liberty." ${ }^{39}$

When Constant advised Bonaparte on the creation of a new constitution during the Hundred Days, he argued (against Bonaparte's inclinations) in favor of a new hereditary

37 The supposed neutrality of the aristocratic class was closely linked with their judicial role in the House of Lords and the parlements. Generating a neutral power that could take the place of the hereditary class was a long-term preoccupation of Constant's constitutional thought.

${ }^{38}$ Constant, Fragments, Henri Grange ed. (Paris: Aubier, 1991 [1810]), p. 118.

${ }^{39}$ Constant, Fragments, p. 208. 
aristocracy. The emperor did not wish to be challenged, and in any event had no suitable candidates - the traditional aristocrats were his enemies. Constant, however, called a hereditary aristocracy "indispensable" for a constitutional monarchy. He would certainly have rather had a republic with no hereditary distinctions; but after the republic fell, there was a need for an aristocracy to moderate the imperial monarchy. He hoped to prevent the reemergence of feudal privileges, but to create a hereditary house parallel to the House of Lords.

In the Memoirs sur les Cent-Jours, there is a passage that begins much the same way, reporting the same arguments of Bonaparte against an aristocracy. But now Constant says that his longstanding doubts about a monarchy without an aristocracy had likely arisen because he, like Montesquieu, was "seduced" by the example of the British constitution. Here Constant himself criticizes the creation of a new, imperial, aristocracy—but not on rationalist or egalitarian grounds. Instead, he maintains that "nothing is created by artifice" in politics. "The creative force in politics, like the vital force in the physical world, cannot be supplemented by any act of will or by any act of law;" ${ }^{40}$ rather, the spirit of the age and of a people would in some important way shape political developments and institutions. This is a Montesquieuian critique of one of Montesquieu's doctrines, and returned Constant to one of the themes of SCUBonaparte's status as a usurper, the inability to create new bloodlines and institutions and traditions from scratch that would have the same legitimacy as those that had come before. It moreover recalls the comment that it would be irrational to deliberately create the diversity in local laws, weights, measures, and so on that Constant defended in his chapter on uniformity.

In other words, Constant was torn between two Montesquieuian impulses. He perceived the need for an intermediate and independent body of aristocrats to balance the Emperor; but

\footnotetext{
${ }^{40}$ Tracy, The Commentary, p. 317
} 
such a body would be a deliberate and artificial creation, out of keeping with the spirit of the nation and of the age. In his later writings and political work under the Restoration it seems to me that we can see the same dynamic. The social background, the spirit of the society in which Constant lived, was one that had been shaped by the Revolution and what followed it. Counterrevolution no more appealed to him in the 1820 s than it had in the $1790 \mathrm{~s}^{41}$ —and in both decades one of his arguments against counter-revolution was that it would be at odds with changes in social character that had taken place. He argued that reforms should not outpace social change and that customs should be allowed to evolve freely without being coercively rushed by the state, but also, and for the same reasons, that political reactions should not attempt to undo social change that has already taken place.

None of this is to say that Constant endorsed the particular group privileges of the ancient constitution. He admired Montesquieu deeply but always saw him from across a deep Revolutionary break, and did not wish to return to the ancien régime. He was keenly aware of the costs to individual freedom of state-sanctioned group privileges. He wrote against the guild system and chartered monopolistic corporations with a concentrated fury not seen even in Smith, whose arguments he relied upon and cited freely. ${ }^{42}$ Constant's pluralism had to differ from Montesquieu's; the post-revolutionary world he inhabited differed too greatly from the ancien régime. But it is a reasonable assessment to say that "Montesquieu's dread of uniformity

${ }^{41}$ Constant, "Des Réactions Politiques" (1797) in Oeuvres Politiques, Charles Louandre, ed. (Paris: Charpentier et Cie, 1874).

42،"Of Privileges and Prohibition,” in Book XII: On Government Jurisdiction over Economic Activity and Population, in Principles of Politics Applicable to All Governments, Dennis

O’Keefe trans. (Indianapolis: Liberty Fund, 2003). 
resonated in the writings of his nineteenth-century followers, especially Benjamin Constant, in response to the imposition of the Code Napoleon, and Alexis de Tocqueville, in the face of what he perceived to be increased political centralisation." 43

V.

According to popular understanding, it is in Tocqueville above all that we might expect to find an appreciation of a pluralism that arises out of freely-formed voluntary associations. He was, after all, the theorist of the "art of associating," the one who saw and appreciated the Americans' ability and eagerness to be "freely and constantly forming associations" both in political life and in the pursuit of their various social ends. He witnessed phenomena in American society that one might think solved the problem of pluralism without privilege: asocial sphere of free and open associational creation, entry, and exit. As Tocqueville understood it, the associational world he found among the Americans differed from ancien régime pluralism among the corps not only by its equality but also by its fluidity. The corps were longstanding; Americans had mastered the art of associating anew, creating new associations easily, almost casually, for reasons great or small.

Tocqueville identified one root of this art in the American inheritance from English dissenting Protestantism, but perhaps overlooked others in the new American models of economy and law. Eighteenth and early nineteenth uses of the phrase "civil society" referred mainly to the development of what was also called commercial society, and also to the modern unified legal system that underlay commercial society. Civil society replaced the world of privilege - including trading companies with monopolistic privilege, churches with ecclesiastical

\footnotetext{
${ }^{43}$ Tomaselli, "Spirit of Nations," pp. 30-31
} 
jurisdictional privilege, and nobles with status privilege - with a unified free and equal legal system. This system importantly laws governing commercial exchange, such that Hegel identified "civil society" with the open market and Marx dismissed it as bourgeois civil society. It was just such an open access legal regime-associated with the move toward a democratized law of commercial incorporation - that allowed for the associational world Tocqueville saw, the associational world to which we most often reserve the phrase "civil society" today.

Yet, as with Smith and Constant, matters are not so simple, and Tocqueville cannot simply be read as celebrating an order of competitive associational life. The animating concern of Tocqueville's two greatest works is that the conjoined historical movements toward equality and centralization will leave despotism impossible to resist and freedom impossible to defend. He was clear in Democracy in America that his concerns were either European or universal, not narrowly American (though the American canonization of Tocqueville is prone to overlook this). In the penultimate chapter of volume 1 he refers to both the mores that once kept government limited, and to the institutions that did so such as "the prerogatives of the nobility, of the authority of sovereign courts, of the rights of corporations, or of provincial privileges, all things which softened the blows of authority and maintained a spirit of resistance in the nation... political institutions which, though often opposed to the freedom of individuals, nevertheless served to keep the love of liberty alive in men's souls with obviously valuable results... When towns and provinces form so many different nations within the common motherland, each of them has a particularist spirit opposed to the general spirit of servitude; but now that all parts of a single empire have lost their franchises, usages, prejudices, and even their memories and names and have grown accustomed to obey the same 
laws, it is no longer more difficult to oppress them all together than to do this to each separately.",44

Here we see not only a précis for his study of the French old regime decades later; we also find by implication the animating questions of Democracy in America itself. Have the Anglo-Americans so far avoided this descent into servility? If so, how, and what can be learned from them about how to maintain liberty in a democratic age? In old regime France he saw the gradual erosion of intermediate bodies by a centralizing and homogenizing power that became almost irresistible as it aligned with the world-historical force of democratization. In the France of his own day he saw what he took to be the direction of the modern world: democratic equality and statist centralization reinforcing each other and grinding down freedom, distinctiveness, and accomplishment. In contemporaneous America he saw a democratic society that was resisting these trends, in part thanks to local government and to voluntary associations. But in the American future he saw the possibility of "soft despotism" of homogeneous mediocrity and centralized bureaucratic paternalism.

While both Democracy in America and The Old Regime and the Revolution offer famously complex and multi-causal accounts, group life and decentralized government figure prominently in each. The Americans benefited from their institutions of local self-government and from their mania for forming voluntary associations. And the French old regime, by the time of the Revolution, was ready to collapse into a democracy that eventually yielded Bonaparte's despotism in large part because the Bourbon kings had centralized the state so dramatically, undermining urban liberty, provincial liberty, and the privileges of the corps so effectively.

\footnotetext{
${ }^{44}$ Toqueville, Democracy in America. J.P Mayer ed. (New York: Harper \& Row Publishers, $1969[1835 / 1840])$, henceforth $D A$, pp. 312-313.
} 
Tocqueville described medieval Europe as being everywhere much the same, with provincial liberties and urban self-government coexisting with feudal privileges and assemblies of the Estates. But - and this is the central thesis of the book - that shared order was eroded and replaced by a centralized state gradually over the course of early modernity, not suddenly by the Revolution. By the eighteenth century, "the ancient constitution of Europe" was "half-ruined everywhere" $^{45}$ and no longer able to check absolutist monarchs. At the highest level of abstraction, Tocqueville attributes this to the increasing equality of condition over the later Middle Ages and early modernity, a change in historical stage from feudal inequality to democratic equality. "The nobles were already beaten down and the people had not yet risen; the former were too low and the latter not high enough to hinder the movements of power."46 Germanic customary law had been supplanted by Roman civil law, a "law of servitude," opportunistically deployed across the continent by monarchs set on establishing their "absolute power" "on the ruins of the old liberties of Europe." ${ }^{47}$ Tocqueville offers a history of royal suppression of provincial liberties, of urban self-government, and of guild and corps privileges, as well as of the deliberate Bourbon undermining of the social role of the nobility.

The decayed institutions of the eighteenth century created a paradoxical situation for the old regime. On the one hand, they were unloved, indeed often detested. A nobility that no longer had any useful purpose in the countryside retained feudal privileges and immunity from

\footnotetext{
${ }^{45}$ Alexis de Tocqueville, The Old Regime and the Revolution, Volume 1. François Furet and Françoise Mélonio, eds., Alan S. Kahan, trans. (Chicago: University of Chicago, 1998 [1856]), p.
} 103

${ }^{46}$ Old Regime, p. 259

${ }^{47}$ Old Regime p. 258. 
taxation, and the wealthy urban classes naturally resented them for it. Moreover, they served to divide people against each other. While all were becoming more alike in social fact, they remained sharply legally and politically differentiated, and mutual antagonism resulted. But such freedoms as remained, such limits on royal absolutism as still existed, were thanks to these unloved institutions. They "preserved the spirit of independence among a great number of subjects, and inclined them to stiffen their necks against abuses of authority" ${ }^{\prime 4}$.

And so Tocqueville emphasized the role of the prerevolutionary corps intermédiaires, at the same time that he described the inevitability of their decline. Like Montesquieu and Constant before him, he acknowledged their privileges and prerogatives to have been often "odious in themselves," and he thought that they became progressively more intolerable as French society became leveled and homogenized. The sprit de corps found in the nobility, the clergy, the lawyers, and each city's bourgeoisie, their commitment to the group's privileges and rights of self-rule, provided them with both the motive and the means to resist royal despotism.

About the parlements in particular, Tocqueville thought much as Constant had; their role in government "was a great evil which limited a greater one." Tocqueville wrote admiringly about the parlementaires' resolve during the dissolution of the Parlement of Paris in 1771. All of them accepted their loss of status "without a single one of them personally surrendering to the royal will," inspiring other judges and lawyers to stand with them and refuse to cooperate with this suspension of legality. However socially unjust their position was, the parlementaires proved themselves to be courageous and committed defenders of liberty and the rule of law: "I know of nothing greater in the history of free nations than what happened on this occasion." ${ }^{49}$

\footnotetext{
${ }^{48}$ Old Regime, p. 172

${ }^{49}$ Old Regime, p. 178
} 
VI.

North, Wallis, and Weingast analyze the "doorstep conditions" for the transition from limited access to open access orders in terms of impersonality and equality. This means, among other things, that elite privileges and power politics be transformed into common, impersonal rights for members of the elite, subject to the rule of law; and that among these elite rights are the right to create perpetually-lived impersonal corporate organizations. Crossing the threshold consists in part in extending the right to those legal and organizational resources to non-elites. Privilege and personality give way to equal access pluralism.

In Tocqueville's analysis of the behavior of the parlementaires and their supporters, we can see that even within the doorstep stage, there might be tensions among these desiderata. The parlements defended the rule of law among elites in ancien régime France; they did so from a position of personal aristocratic privilege; and their status-oriented, personalistic willingness to defend their status provided crucial motivation for them to act in defense of the rule of law. Members of the corps of the parlementaire nobility and members of the lawyers' guild were willing to act oppositionally, standing against the crown in defense of their status and prerogatives. And on the other side of the Revolutionary transition, in the midst of France's step across the threshold into an open access order, Tocqueville worried that without this motivational energy, opposition would be lacking. This, it seems to me, is the kind of thought that runs through these pluralist liberals across the transition from the mature natural state to the early open-access order. 
We might fairly read the late Ernest Gellner's post-1989 writings on liberal democracy and civil society as, in part, a celebration of open access orders. ${ }^{50}$ While he did not anticipate the North, Wallis, and Weingast arguments in full, he shares their emphasis on the character of associational and organizational life, the impersonality of the state, and access to political resources including military power. And he sees this order as crucially individualistic — not in the sense that in civil society we lack associations, but in the sense that these are merely associations, nothing thickeror deeper.

"Modular man," Gellner wrote of his ideal-typical inhabitant of civil society, "is capable of combining into effective associations and institutions, without these being total, multistranded, underwritten by ritual and made stable through being linked to a whole inside set of relationships, all of these being tied in with each other and so immobilized. He can combine into specific-purpose, ad-hoc, limited associations, without binding himself by some blood ritual."

Gellner insists that the organizational triumph of the modern state over its medieval predecessors was one precondition for the emergence of a truly civil society, one in which associations may be formed, and exited, at will. This eliminates the potency of group ties to shape access to political and military power, because the nation-state has trumped all substate competitors. Gellner's unified account depicts a social world of equal liberal agents creating new voluntary associations as easily, and with the same rules, as they create economic firms or political parties. This is an of idealization of the open access order - a strange word to use for a thinker so chastened as Gellner, but I mean it both in the sense that it is a Weberian ideal type

\footnotetext{
${ }^{50}$ See especially Ernest Gellner, Conditions of Liberty: Civil Society and Its Rivals (New York: Penguin, 1994).

${ }^{51}$ Conditions of Liberty, p. 99.
} 
and in the sense that it was, by Gellner's own moral lights, normatively ambitiously better than really existing open access orders.

Gellner's image of civil society fit neatly with his functionalist account of the emergence of nationalism. ${ }^{52}$ Workers in an industrial economy shed guild identities and inherited employment, and need a modular education that will allow them to perform a variety of jobs in a variety of industrial workplaces. This in turn requires a nationally-homogenous language in which workers can become literate, so that they might move around the country in response to labor needs, and work alongside those whose ancestral dialects might have been incomprehensible to them. In other words, so that individual persons might be able to equally access the labor opportunities in a modern economy, premodern ethnocultural, regional, and linguistic differences must be overcome. The affinities between the industrial firms in this story and the associations in his depictions of civil society are not a coincidence.

These nation-building projects of modern states were just the kind of centralizing pursuits of uniformity that so worried the $18^{\text {th }}$ - and $19^{\text {th }}$-century pluralist liberals. ${ }^{53}$ Faced with such projects, these theorists hoped that pluralism could be recovered without privilege. They regarded the republican terror of faction and disunity as pathological, and appreciated Montesquieu's diagnosis of centralization's evils, but saw that the corps could not and should not survive in a democratic age. But the kinds of pluralism they both sought to legitimize rested more than is often appreciated on ancien régime foundations. The more liberal freedom of association, religious freedom, and local government they hoped could replace the corps still depended on extra-legal social pluralism for its energy. The horizontal competition of firms and

\footnotetext{
${ }^{52}$ Ernest Gellner, Nations and Nationalism, Ithaca: Cornell University Press, 1983.

${ }^{53}$ While he lies beyond the scope of this essay, here I would add Lord Acton to the theorists I have discussed here. See my Rationalism, Pluralism, and Freedom, chapter 9.
} 
associations, with persons joining and leaving them at will, lacks a mechanism for the vertical constitutional constraint of centralizing states.. And the abolition of privilege, the democratization and opening of organizational life, the shift from nobles defending their honor or lawyers standing on their guild rights to "modular man" putting on and taking off associational identities, may make that oppositional energy hard to come by. 